\title{
Corporate Governance Mechanisms and Firm Performance: Evidence from the Emerging Market Following the Revised CG Code
}

\begin{abstract}
Purpose - This study examines the extent to which board characteristics and ownership structure affect firm performance with specific focus on providing new empirical insights following the revised Corporate Governance (CG) code 2012.

Design/methodology/approach - This study uses a sample of non-financial firms listed on Pakistan Stock Exchange (PSX)-100 index for the years 2011 to 2014. Firm performance is measured by accounting-based performance indicators (ROA and ROE) and market-based performance indicators (Tobin's Q and MTB). This study employs multivariate regression techniques including Fixed Effects Model (FE) and Two-Stage Least Squares (2SLS).

Findings - The findings show that board diversity increases over the two time periods (Pre2012 and Post-2012), whereas there are cases that companies have not fully complied with the revised CG code 2012 in terms of board independence. In addition, the multiple regression results show that firm performance is negatively and significantly associated with institutional ownership. Nevertheless, the results show that board size, board independent, board diversity and board meetings do not have significant impact on firm performance. The findings are fairly consistent and robust across two time periods (Pre-2012 and Post 2012) and a number of econometric models that sufficiently address the potential endogeneity problems.

Originality/value - To the best of our knowledge, this is the first empirical study which investigates the impact of the compliance and implementation of 2012 corporate governance code on firm performance in Pakistan. This study is different from the most prior studies in that we utilize independent non-executive directors rather than conventional non-executive directors to measure board independence.
\end{abstract}

Keywords: Corporate governance, Board characteristics, Gender diversity, Ownership structure, Firm performance, PSX-100 index

Paper type: Research paper 


\section{Introduction}

Existing literature suggests that better governance plays an important role in corporation as it provides oversight, mitigates scandals, increases a firm's access to external finance, ensures efficient allocation of resources and fosters better relationships among stakeholders (Claessens and Yurtoglu, 2013). Corporations in both developed and emerging markets have employed different corporate governance mechanisms including (I) board size; (II) executive compensation; (III) debt; and (IV) the market for corporate control to ensure company is run effectively and stakeholders are protected. Over recent years calls in academic research, policy and media for reform in corporate governance have intensified. In line with such calls, corporations such as BlackRock, Vanguard and State Street, which constitutes three of the world's largest asset managers with about $\$ 11$ trillion assets, recently expanded their corporate governance teams to ensure they effectively monitor the activities of the companies they invest in (Marriage, 2017).

Evidence from previous studies has been mixed on the directions of the implication of corporate governance on firm performance. It is suggested that the effectiveness of corporate governance in emerging markets is different to that in developed markets, as emerging markets are characterized by firms that are closely held, lack appropriate mechanisms to enforce shareholders' legal rights, and are in need for transparency (Gibson, 2003). To this effect, several studies were instituted that examined the impact of corporate governance mechanisms on firm performance in the context of emerging markets. For example, Bhatt and Bhatt (2017) examined the effect of Malaysian code of corporate governance on the performance of listed firms in Bursa Malaysia. Arora and Sharma (2016) investigated the impact of corporate governance on firm performance in the context of India. It is evident that in spite of the attempts at improving the corporate governance in Pakistan, there is limited empirical study channeled to investigate its effects.

This study seeks to extend as well as make a number of contributions to the extant CG literature. First, to the best of our knowledge, this is the first empirical study which investigates the impact of the compliance and implementation of 2012 corporate governance code on firm performance in Pakistan. Second, there is a requirement for the firms to evaluate the performance within two years of implementation of CG code 2012 by the SECP. Therefore, we offer timely evidence by examining whether board characteristics (board size, board independence, board diversity and board meeting) and ownership structure (managerial ownership and institutional 
ownership) may enhance firm performance using a sample of non-financial firms listed on the Pakistan Stock Exchange (PSX) 100 index following changes in regulatory environment. Third, different from most prior studies, we utilize independent non-executive directors rather than conventional non-executive directors to measure the board independence. Fourth, we use alternative econometric models to address the endogeneity problems. Finally, we split our sample into two sub-samples in order to investigate whether the CG mechanisms have changed over two time periods and the revised CG code 2012 has any impact on the firm performance during different sample periods (e.g. pre-2012 and post-2012).

The reminder of the paper is organized as follow. Section 2 reviews the literature and develops the hypotheses. Section 3 outlines the methodology and data and section 4 discusses the findings of the paper. The final section presents the summary and conclusion.

\section{The development of corporate governance in Pakistan}

Like other countries around the world, Pakistan has been actively pursuing the CG reforms over the last fifteen years. The original CG code was introduced in 2002 by Securities Exchange Commission of Pakistan (SECP) and it was made mandatory for all Pakistani listed firms (Tariq and Abbas, 2013). The main objective of the code is to improve the confidence of investor in the way a company is operated and to tackle the problems that are related to developing economies such as failure to pay dividends over a long period (Ashraf and Ghani, 2005). However, the implementation of this code resulted in de-listing of firms because they were not able to understand the regulations of the code and in 2006 CIPE (Centre for International Private Enterprise) conducted a seminar to discern whether firms understood the code and to determine whether the code required any modifications (Fudda, 2007). Then, the revised CG code was issued in 2012 which was a vital move to make directors more accountable (Awan, 2014). Moreover, the Pakistan Institute of Corporate Governance (PICG) further enhances the awareness of the advantages of implementing the CG code (Salman and Siddique, 2013).

The earlier CG code 2002 recommended that one independent director should sit on the board, the executive directors should not be more than seventy-five percent of the total board members, chairman of the board and audit committee (AC) should preferably be a nonexecutive director (NED), and ACs were allowed to have executive directors as their members (SECP, 2002). However, the revised CG code 2012 stipulated that the board should have at 
least one independent director, the executive directors cannot be more than one-third of the total number of board members, CEO (Chief Executive Officer) and Chairman should not be the same person, chairman of the board must be a NED, chairman of the AC must be an independent director and AC should consist of NEDs only (SECP, 2014). Noticeably, the changes on the number of executive directors and non-executive directors suggests that the government is aware of the increasing importance of NEDs which brings fresh perspective, experience and networks to the firms but also aims to reduce the power of executive directors and to increase the independence of the board so that the boards can be properly managed and monitored.

Board diversity was not specified in the original CG Code 2002 while the revised CG code 2012 recommended gender diversity on the boards (SECP, 2002 and 2014). This is probably due to the trends and recent practices of other countries. For instance, the 2009 Luxembourg CG code recommended gender diversity on the boards, and the 2009 Austria CG code also recommended that both male and female directors should be appropriately represented on supervisory boards (European Commission, 2016). It should be noted that there will be an annual evaluation of the performance of the board within two years of implementation of CG code 2012 (SECP, 2014), therefore it will be interesting to see if the firms have adopted any new recommendations in response to the latest CG code after 2012. To highlight the main changes in the two codes (2002 and 2012), a comparison of the CG code 2002 and the revised CG code 2012 is presented in the Table 1 and these provisions cover six main areas: board evaluation, board independence, executive directors, leadership, audit committee and board diversity.

Insert Table 1 about here

\section{Literature review and hypotheses development}

\subsection{Board size}

The size of the board and its composition are rational responses to the conditions of the external environment, current internal situation and previous financial performance of a firm (Pearce and Zahra, 1992). Sheikh et al. (2013) argue that firms benefit from a large board size as the expertise and skills of large members would be utilized to improve firm performance. In addition, the efficiency perspective of the neo-institutional theoretical framework indicates that 
large board size increases monitoring, as dominant CEOs might find it difficult to influence all the members of the board (Elmagrhi et al., 2016). Another strand of the literature proposes an opposing arguing to the above mentioned. For example, a large board size may find it difficult to reach a consensus that may result in unnecessarily scheduling meetings (Cheng, 2008; Arora and Sharma, 2016). To the extent that time is wasted in making investment decisions, a firm's performance may be affected. Nguyen and Faff (2007) show that large board size erodes firm value as it may be costly to resolve conflicts and coordinate communication flows and decisions among large number of people. They find that smaller boards have positive impact on firm performance, indicating that interests of shareholders are better represented. Therefore, we propose the following hypothesis:

H1. There is a negative relationship between board size and firm performance.

\subsection{Board independence}

Non-executive directors (NEDs) are expected to oversee the utilization of firm resources by executives (Mura, 2007), therefore they help to mitigate the agency problems and safeguard the interests of shareholders (Froud et al., 2008). NEDs have different backgrounds which provide various perspectives to the board and reduces complacency (Mathew et al., 2016) and also have the expertise to provide impartial judgement (Sundarasen et al., 2016). Furthermore, NEDs have their reputation and career at stake which force them to be very careful in ensuring the executive directors always work for the benefit of shareholders. The presence of nonexecutive directors may improve firm performance. The independence of NEDs could provide incentives to advice and monitor the activities of the management, ensuring the interests of shareholders are protected (Mura, 2007; Duchin et al., 2010). Liu et al. (2015) find that stateowned firms having non-executive directors reduce insider self-dealing, improve investment efficiency, and enhance firm performance. Benkel et al, (2006) find that the presence of nonexecutive directors on the board can improve earnings report, as there will be reduced levels of earnings management. Therefore, we propose the following hypothesis:

H2. There is a positive relationship between board independence and firm performance. 


\subsection{Board diversity}

Prior research demonstrates that firm performance is impacted by board diversity (Hillman, 2015; Kumar and Zattoni, 2016). For example, board with a different gender, ethnicity, and/or cultural background would be more likely to make suggestion, ask questions and allocate more time to board monitoring thereby improving performance than directors with more traditional backgrounds (Adams and Ferreira, 2009). In support of resource dependence theory, studies suggest that a board with diverse experiences, skills and knowledge would make better decisions that improve overall performance of the company (Hillman, 2015). Nguyen and Faff (2007) report that board diversity increases the effectiveness of management and enhance their leadership role, creativities and innovation. Female representation on the board, in particular, improves board monitoring role, reduces agency costs (Farag and Mallin, 2016), and enhances the quality of board discussions that would increase firm performance. Further, men consider only the economic effects when making corporate decisions whereas women consider every situation that affect the quality of their decision (Hillman, 2015). Thus, we propose the following hypothesis:

H3. There is a positive relationship between board diversity and firm performance.

\subsection{Managerial ownership}

According to agency theory, directors are opportunistic unless they have proper incentive (Abdallah and Ismail, 2017; Kumar and Zattoni, 2016), so managerial ownership is important as it acts as an incentive mechanism. The alignment theory argues that to the extent that managers hold shares in their firm, the interests of the shareholders is better served (Jensen and Meckling, 1976). Stemming from the agency cost reduction theory, it is argued that managerial shareholding reduces the costs arising from conflict of interests between managers and shareholders, thus improving access to external finance and reducing cost of capital (Claessens and Yurtoglu, 2013). On the other hand, the entrenchment theory literature argues that increase in managerial shareholding will increase voting power of managers which will allow managers to pursue decisions that only cater to their interests (Kwansa et al., 2014). Weir (1997) find that managers of acquired firms are less motivated to pursue the interests of the shareholders due to holding significantly lower shares in the firms. Using Malaysian non-financial firms, 
Haniffa and Hudaib (2006) report a negative association between managerial shareholding and firm performance. In line with existing studies, we propose the following hypothesis:

H4. There is a negative relationship between managerial ownership and firm performance.

\subsection{Institutional ownership}

Institutional investors can affect firm performance, as they have the resources to monitor and scrutinize the activities of the management effectively thus dissuading managers from undertaking wasteful investments (Alipour, 2013). Having higher level of share ownerships provides institutional investors with incentives to vote with their feet thus mitigating managers' opportunistic behaviour (Elmagrhi et al., 2016; Parrino et al., 2003). More recently, institutional investors have been found that they are more willing to utilise their ownership rights to persuade management to pursue activities in favour of shareholders (Cornett et al., 2007). Institutional investors can showcase their power by transacting shares on the market or by influencing the strategies of the firm through representation on the board (Chaganti and Damanpour, 1991). However, institutional investors may collude with the firm's executives which will negatively affect firm performance (Jong et al., 2005). Extant literature provides evidence that institutional investors can terminate poorly performing Chief Executive Officers (CEOs) to ensure firm performance improve over time (Aggarwal et al., 2011). Institutional shareholders through activism and herding can voice their dissatisfaction over bad firm performance by forcing CEO turnover (Parrino et al., 2003). Thus, we propose the following hypothesis:

H5. There is a negative relationship between institutional ownership and firm performance.

\subsection{Board meeting}

Board meeting has implications on firm performance through strategic advice about investment opportunities (Vafeas, 1999). For example, managers' interests are better aligned with those of shareholders when outside directors attend meetings. This is because outside directors are more likely to collect information, make decisions and monitor management activities during board meetings (Adams and Ferreira, 2009). Vafeas (1999) shows that frequency of board meetings leads to increased growth opportunities and merger and acquisition. Mishra et al (2009) point 
out that board meetings are informative corporate events that could lead to informed trading through significant changes in the bid-ask spread. Demirtas (2017) reports that returns and premiums of the shareholder at target firm increases when the directors meet early after the beginning of a sale process increases. By contrast, another stream of studies argues that there is a negative association between board meetings and firm performance. Given the limited time spent at board meetings, directors would not make meaningful exchange of ideas that would improve firm performance. Ebrahim (2007) finds that high meeting frequency leads to high level of earnings management. Studies also find that high meeting frequency is positively related with the probability of committing fraud, which is likely to slow down earnings per share (EPS) growth (Chen et al., 2006). Thus, we propose the following hypothesis:

H6. There is a negative relationship between board meeting and firm performance.

\section{Research design}

\subsection{Data and sample}

Our sample comprises all the non-financial firms listed on Pakistan Stock Exchange (PSX)100 index the years 2011 to 2014. Consistent with prior corporate governance literature (Elmagrhi et al., 2016; Sheikh et al., 2013), financial firms are excluded from our initial sample since they are highly leveraged and subject to different regulations. We consider the years from 2011 to 2014 because it allows us to evaluate the effects of the revised CG code in Pakistan and its implication on firm performance. PSX-100 index covers $85 \%$ of the total market capitalization of Pakistan Stock Exchange (Malik and Zahoor, 2016). The data was manually collected from annual reports and Financial Times. Firms have to meet the following criteria in order to be included into the final sample: (a) annual reports of firms are available for the whole sample period, (b) firms' financial performance data can be accessed for the whole sample period, (c) firms have to be continuously listed on the Karachi Stock Exchange from 2011 to 2014. Finally, firms from seven industries are included and Table 2 summarize the composition of the final sample.

Insert Table 2 about here 


\subsection{Empirical model and variables measurement}

In order to assess the effects of board characteristics and ownership structure on firm performance, we use both univariate and multivariate analyses. In order to choose the most suitable estimation between pooled regression and panel fixed/random effects, two types of tests were performed. First, both F-test and Lagrange Multiplier (LM) test are significant $(\mathrm{p}<0.05)$ for all performance measures therefore panel data analysis is preferred. Second, we conduct the Hausman test (Hausman, 1978) to decide between fixed effect and random effect models. We find that Hausman test is significant $(p<0.1)$ for all performance measures which indicates fixed effects model should be utilized. The results are reported in Appendix 1. In order to address the concerns of heteroscedasticity and serial correlation, this study utilizes fixed effects model with standard errors clustered at firm level. We present the results for both fixed-effects and OLS for comparison purposes. Using firm performance as dependent variable, we develop the following model:

$\mathrm{FP}_{\text {it }}=\beta_{0}+\beta_{1} \mathrm{BS}_{\mathrm{it}}+\beta_{2} \mathrm{IND}_{\text {it }}+\beta_{3} \mathrm{DIV}_{\mathrm{it}}+\beta_{4} \mathrm{MO}_{\text {it }}+\beta_{5} \mathrm{IO}_{\text {it }}+\beta_{6} \mathrm{BM}_{\mathrm{it}}+\beta_{7} \mathrm{LEV}_{\text {it }}+\beta_{8} \mathrm{AGE}_{\mathrm{it}}+$ $\beta_{9} \mathrm{SIZE}_{\mathrm{it}}+\varepsilon_{\mathrm{it}}$

Where FP (firm performance) is measured by both accounting-based measures: return on assets (ROA) and return on equity (ROE) and market-based measures: Tobin's $Q(Q)$ and market to book (MTB). BS is board size; IND is the percentage of independent non-executive directors; DIV is diversity which is measured by the percentage of female directors sitting on the board; MO is managerial ownership; IO is institutional ownership; BM is board meeting. Leverage (LEV), firm age (AGE) and firm size (SIZE) were used as control variables. Industry effect and year effect was controlled through dummy variables. Table 3 defines the all the dependent, independent variables and control variables.

Insert Table 3 about here

Following the previous research (Mashayekhi and Bazaz, 2008), the accounting-based firm performance is measured by return on assets ratio (ROA), i.e. profit before tax as percentage of total assets and return on equity ratio (ROE), i.e. profit after tax as percentage of total equity, the market-based performance is measured by Tobin's Q, i.e. the book value of long term debt and market value of the equity divided by the book value of the total asset and market to book ratio (MTB), i.e. market value of firm divided by book value of firm. We use board size (BS), 
board independence (IND), board diversity (DIV), managerial ownership (MO) and institutional ownership (IO) as corporate governance variables in the regression model. We also include a number of control variables in the regression given their effects on firm performance. Javed and Iqbal (2006) suggests that the effect of firm size should be controlled. We use natural log of sales to control for firm size (SIZE) as it was also used by Sheikh et al., (2013). We use ratio of total debt to total assets to measure leverage (LEV). Firm age (AGE) is also used as control variable as experienced firms are better equipped to strategize which results in better performance. Firm age is defined as years since incorporation (Yasser, 2011). If a firm belongs to a specific industry then the performance of the firm can be affected by specific characteristics of that industry. To control for the industry effect and year effect, dummy variables for industries and years were also included (El-Faitouri, 2014).

\section{Empirical results}

\subsection{Descriptive statistics}

Panel A of Table 4 presents the descriptive statistics for all the variables. Board size (BS) ranges from 6 to 15 with a mean value of 8.560, which means, on average, there are 9 members sitting on the board which is consistent with the prior study by Yasser (2011). The mean value of IND is 0.232 , meaning, on average, independent NEDs comprised approximately $23.2 \%$ of the board. In order to explore the impact of the revised CG Code 2012, we divide our sample into two periods: Pre-2012 and Post-2012 and any changes across these two periods will now be considered in more detail. Panel B of Table 4 shows the changes across the two types of performance measures (accounting-based and market-based) and it can be seen that the firm performance has been improved during the two periods. For instance, ROA increased from 11.924 (Pre-2012) to 14.272 (Post-2012) with a change of $19.69 \%$ and similarly ROE increased from 17.586 (Pre-2012) to 21.003 (Post-2012) with a change of 19.43\%. There was a substantial increase in the market-based performance measures and the findings show that Tobin's q increased by $63.28 \%$ from 1.386 to 2.263 whilst MTB has doubled from 1.842 to 3.748 during two periods.

Panel $\mathrm{C}$ of Table 4 shows the changes across two time periods in CG mechanisms and there was a variation between different mechanisms. Board size (BS) has been quite stable and does not change during the Pre-2012 and Post-2012 periods and ranges from 6 to 15 with a mean 
value of 8.56. Board independence (IND) shows that there was a significant decrease of $22.10 \%$ from a mean value of 0.267 to 0.208 over the two time periods and suggest that some companies have not fully complied with the revised CG code 2012 in terms of "one-third of the board are recommended to be independent directors". Moreover, the minimum value of IND was 0 across the two periods indicates that some companies have not complied the revised CG code 2012 as which the company must has "at least one independent director on the board". Percentage of female directors (DIV) sitting on the board increased from 0.044 (Pre-2012) to 0.054 (Post2012) with a change of $22.72 \%$, which seems to follow the recommendation by the new CG code 2012 that "diversified board is recommended". In terms of the ownership structure, managerial ownership decreased from 11.473 to 11.036 while institutional ownership increased from 0.792 to 0.846 over the two time periods. Finally, board meeting has slightly decreased from 5.29 to 5.14 with a very small change of $2.83 \%$ across two periods.

Insert Table 4 about here

\subsection{Correlation matrix}

Table 5 reports the results of Pearson correlation matrix for all the variables. It indicates that there is no potential multicollinearity in our regression models as the level of correlation between variables is relatively low. Furthermore, we use the variance inflation factor (VIF) to double-check the potential issue of multicollinearity. Yusr et al. (2012) suggests that if tolerance value is more than 0.1 and the value of VIF is less than 10, the issue of multicollinearity is not severe. Table 6 presents tolerance and VIF values and the values of VIF well below 10 and tolerance values are also above 0.1 , indicating that there are no multicollinearity problems.

Insert Table 5 and 6 about here

\subsection{Regression results and discussion}

Table 7 reports the regression results from Fixed-effect. In Table 7, Column (1) and (2) are estimated using ROA and ROE as dependent variable. Firstly, the coefficient of board size (BS) is positive for both ROA and ROE, but the results are insignificant. Therefore, H1 is not supported. This indicates firms could benefit from a large board size as the expertise and skills 
of large members would be utilized to improve firm performance. The result is consistent with the studies of Malik et al. (2016) and Kutum (2015) but contradicts with prior studies such as Dharmadasa et al. (2014) and Mashayekhi and Bazaz (2008). Secondly, although the percentage of independent non-executive directors (IND) is positively related to ROA and ROE, but the results are insignificant. Thus, $\mathrm{H} 2$ is not supported. This suggests that board with more independent non-executive directors increase the firm performance consistent with the findings of prior studies (Ali and Nasir, 2014; Javeed et al., 2014; Yekini et al., 2015). However, the insignificance of the result could be attributed to the very low percentage of independent NED of $23 \%$ compared to the requirements of the revised code that executive directors should not be more than one third. Yekini et al. (2015) provided evidence that companies with two-third NEDs reported higher and quality performance over those with lesser percentage of NED. Thirdly, gender diversity (DIV) is negatively and significantly associated with ROA and ROE. Therefore, H3 is not supported. The result supports the view that great gender diversity may result in more conflicts and thus decision making may be more difficult and less effective. Fourth, managerial ownership (MO) is negatively correlated with ROA and ROE but the result is insignificant. Therefore, H4 is not supported. The result supports the entrenchment theory which argues that increase in managerial shareholding will increase voting power of managers which will allow managers to pursue decisions that only cater to their interests (Kwansa et al., 2014). Fifth, institutional ownership (IO) is negatively and significantly associated with ROA and ROE, thus H5 is supported. The result is consistent with the findings of Jong et al. (2005) and Aljifri and Moustafa (2007). The evidence contradicts to the assumption that firms with increased institutional ownership are associated with less information asymmetry and agency problems, which can positively affect firm performance. Finally, board meeting (BM) is negatively but insignificantly associated with ROA and ROE. Therefore, H6 is not supported. Previous studies have expressed the concerns over frequent board meetings which may reduce the limited time non-executives spend with the firm and the resources instead should be utilized in more productive activities.

Insert Table 7 about here

\subsection{Additional analyses}

In order to further examine the robustness of our results, we conduct a number of additional tests. First, we replace the accounting-based measures of ROA and ROE with market-based 
measures of Tobin's Q and MTB as dependent variable and re-estimate the effects of CG mechanisms on firm performance. The results are reported in Column (3) and (4) of Table 7. Overall, the findings are similar to the results reported in Column (1) and (2), this indicates our results are robust to using alternative market-based performance measures.

Second, we adopt an instrumental approach to address the potential endogeneity issues which might arise from the relationship between firm performance and CG mechanisms. More specifically, following the existing literature (Fang et al., 2009), we use the lagged value of board characteristics (board size, board independence, board diversity, board meeting) and ownership (managerial ownership and institutional ownership) as instruments that are correlated with board and ownership variables but are not correlated with the error term. Therefore, to control for unobserved firm level characteristics, we re-estimate Model 1 to 4 of Table 7 using the Two-Stage Least Squares (2SLS) model. The results reported in Model 1 to 4 of Table 8 are similar to the results reported in Table 7, suggesting that our findings are robust to the presence of potential endogeneity issue.

Insert Table 8 about here

Third, due to the fact that there is a requirement for the firms to evaluate the performance within two years of implementation of the new CG code 2012, this provides us a good opportunity to examine the impact of the revised code on firm performance. Table 9 shows the impact of corporate governance mechanisms on firm performance for the period of Pre-2012 and overall findings show that most of the CG mechanisms are not statistically significant in determining the firm performance. For instance, board size (BS) and board diversity (DIV) have positive impact on firm performance, however the results are not statistically significant. Institutional ownership (IO) is negatively and significantly associated with firm performance measures (accounting and market based). The results are similar to the findings reported in Table 7 and 8 and it is consistent with the findings of Aljifri and Moustafa (2007). The evidence contradicts to the assumption that firms with increased institutional ownership are associated with less information asymmetry and agency problems, which can positively affect firm performance. Finally, board meeting (BM) is overall negatively related to firm performance although the results are not significant. The findings indicate that the firms tend to have frequent meetings to address different issues from poor performance (Vafeas, 1999). The insignificant 
relationship between CG mechanisms and firm performance could be explained by lacking of detailed CG code before 2012.

Table 10 shows the impact of corporate governance mechanisms on firm performance for the period of Post-2012. It can be seen that overall the findings for the Post-2012 are similar to the Pre-2012 period. For instance, institutional ownership (IO) is negatively and significantly associated with firm performance measures (accounting and market based). However, board independence is positively and significantly related to market-based performance measures (Tobin's q and MTB) which is different from the Pre-2012 period. The findings suggest that board with more independent non-executive directors improve the firm performance (Ali and Nasir, 2014). In terms of board diversity and board meetings, the results suggest they are not statistically significant in affecting firm performance. Overall, the results show that the relationship between firm performance and corporate governance mechanisms is not strongly linked and this may due to the factors that firms in Pakistan did not comply with the new CG code 2012 in the earlier stage which can be seen from the results of descriptive statistics.

Insert Table 9 and 10 about here

\section{Conclusions and suggestions}

This study examines the impact of corporate governance mechanisms on firm performance in Pakistan using a sample of firms listed on PSX-100 index from 2011 to 2014. This study seeks to extend as well as make a number of contributions to the extant literature. First, we contribute to the extant literature by offering new empirical evidence on compliance and implementation of 2012 corporate governance code in Pakistan. Second, we offer timely evidence by examining whether board characteristics (board size, board independence, board diversity and board meeting) and ownership structure (managerial ownership and institutional ownership) may affect firm performance using a sample of non-financial firms listed on Pakistan Stock Exchange (PSX)-100 index following a change in regulatory environment. Third, different from most prior studies, we utilize independent non-executive directors rather than conventional non-executive directors to measure the board independence. Fourth, we use alternative econometric models to address the endogeneity problems. Finally, we split our sample into two sub-samples in order to investigate whether the CG mechanisms changes over two time periods and the revised CG code 2012 has any impact on the firm performance during 
different sample periods (e.g. pre-2012 and post 2012). Overall, the results show that the relationship between firm performance and corporate governance mechanisms is not strongly linked and this may due to the factors that firms in Pakistan did not follow the recommendations of the new CG code 2012 in the earlier stage.

Our findings have important implications for policymakers, regulators, shareholders, companies, government and other countries. First, our results show that the relationship between performance and governance is not strong in Pakistan, indicating that recommendation of the revised CG code 2012 may not be adopted widely within the firms. This provides policymakers and regulators with a strong motivation to find ways to encourage the adoption further. Second, we have found a negative relationship between institutional ownership and firm performance, suggesting that institutional investors have failed to monitor the firms properly. Policymakers or government may think about how to increase shareholder activism, especially institutional investors. Third, we found that the percentage of independent NED is still very low in Pakistan. This finding has important implications for boards and policy makers who are interested in achieving optimal board composition. Since there has been evidence of improved performance with higher NEDs, corporations should take this provision of the revised code seriously and consider increasing the number of their NEDs. Finally, female directors seem still not common in Pakistan and corporations may also think about how to further promote board diversity in the future.

There are some limitations to our study. Our study was restricted with respect to the number of corporate governance variables due to the data limitations although we have used fixed effects models to address this issue. Future studies may consider including other factors (e.g. audit, remuneration and nomination committees, director networks, etc) when data becomes available. Due to the fact that all the data was manually collected from the annual reports, we have used the sample of PSX-100 index over the period of 2011 to 2014. Future studies can extend our study by including more sample firms and cover longer period. Finally, our study mainly uses secondary data and future studies may improve our findings by conducting indepth interviews, questionnaire or case studies to gain insights of corporate governance practices and their relationship with firm performance. 


\section{References}

Abdallah, A. A., and Ismail, A. K. (2017), "Corporate governance practices, ownership structure, and corporate performance in the GCC countries", Journal of International Financial Markets, Institutions and Money, Vol. 46, pp.98-115.

Adams, R. B., and Ferreira, D. (2009), "Women in the boardroom and their impact on governance and performance”. Journal of Financial Economics, Vol. 94, pp.291-309.

Aggarwal, R., Erel, I., Ferreira, M., and Matos, P. (2011), "Does governance travel around the world? Evidence from institutional investors", Journal of Financial Economics, Vol.100 No.1, pp.154-181.

Ali, A., and Nasir, S.B. (2014), "Impact of board characteristics and audit committee on financial performance: A study of manufacturing sector of Pakistan", Research Journal of Finance and Accounting, Vol. 5 No. 7, pp.144-151.

Alipour, M. (2013), "An investigation of the association between ownership structure and corporate performance", Management Research Review, Vol. 36 No. 11, pp.1137-1166.

Aljifri, K., and Moustafa, M. (2007), "The Impact of Corporate Governance Mechanisms on the Performance of UAE Firms: An Empirical Analysis", Journal of Economic and Administrative Sciences, Vol. 23 No.2, pp.71-93.

Arora, A., and Sharma, C. (2016), "Corporate governance and firm performance in developing Countries: Evidence from India", Corporate Governance: The international journal of business in society, Vol.16 No.2, pp.420-436.

Ashraf, J., and Ghani, W.I. (2005), “Accounting development in Pakistan”, The International Journal of Accounting, Vol. 40 No. 2, pp.175-201.

Awan, M. R. (2014), "Corporate governance and SECP: forcing out the bad", available at: http://www.brecorder.com/pages/article/1166085/2014-03-26/corporate-governance-andsecp:-forcing-out-the-bad.html.

Benkel, M., Mather, P., and Ramsay, A. (2006), "The Association between Corporate Governance and Earnings Management: The Role of Independent Directors", Corporate Ownership \& Control. Vol 3 No 4, pp. 65-156.

Bhatt, P.R., and Bhatt, R.R. (2017), "Corporate governance and firm performance in Malaysia", Corporate Governance: The International Journal of Business in Society, Vol.17 No.5, pp.896-912.

Chaganti, R. and Damanpour, F. (1991), "Institutional ownership, capital structure, and firm performance”, Strategic Management Journal, Vol. 12 No. 7, pp. 479-491

Chen, G., Firth, M., Gao, D., and Rui, O. (2006), "Ownership Structure, Corporate Governance, and Fraud: Evidence from China”, Journal of Corporate Finance. Vol. 12, pp. 424-448. 
Cheng, S. (2008), "Board size and the variability of corporate performance", Journal of Financial Economics, Vol. 87 No.1, pp.157-176.

Claessens, S., and Yurtoglu, B.B. (2013), "Corporate governance in emerging markets: A survey", Emerging Markets Review, Vol.15, pp.1-33.

Cornett, M. M., Marcus, A.J., Saunders A. and Tehranian, H. (2007), "The impact of institutional ownership on corporate operating performance", Journal of Banking and Finance, Vol. 31 No. 6, pp. 1771-1794.

Dharmadasa, P., Gamage, P., and Herath, S. K. (2014), "Corporate governance, board characteristics and firm performance: Evidence from Sri Lanka", South Asian Journal of Management, Vol. 21 No.1, pp.7-31.

Ebrahim, A. (2007), "Earnings Management and Board Activity: An Additional Evidence. Review of Accounting and Finance. Vol. 6 No.1, pp.42-58.

El-Faitouri, R. (2014), “Board of directors and Tobin's Q: Evidence from U.K. firms”, Journal of Finance and Accounting, Vol.2 No.4, pp.82-99.

Elmagrhi, M.H., Ntim, C.G. and Wang, Y. (2016), "Antecedents of voluntary corporate governance disclosure: a post-2007/08 financial crisis evidence from the influential UK Combined Code", Corporate Governance: The International Journal of Business in Society, Vol. 16 No. 3, pp. 507-538.

Fang, V. W., Noe, T. H., \& Tice, S. (2009), "Stock market liquidity and firm value", Journal of financial Economics, Vol.94 No.1, pp.150-169.

Farag, H., and Mallin, C. (2016), "The influence of CEO demographic characteristics on corporate risk-taking: Evidence from Chinese IPOs", The European Journal of Finance, pp. 130.

Froud, J., Leaver, A., Tampubolon, G., and Williams, K. (2008), "Everything for sale: How non-executive directors make a difference”, The Sociological Review, Vol.56, pp.162-186.

Fudda, M. (2007), "Survey of Corporate Governance Practices in Pakistan", available at: http://www.cipe.org/blog/2007/09/04/survey-of-corporate-governance-practices-in-pakistan/.

Gibson, M.S. (2003), "Is corporate governance ineffective in emerging markets?", The Journal of Financial and Quantitative Analysis, Vol.38 No.1, pp.231-250.

Haniffa, R., and Hudaib, M. (2006), "Corporate governance structure and performance of Malaysian listed companies", Journal of Business Finance \& Accounting, Vol. 33 No. 7, pp. 1034-1062.

Hillman, A.J. (2015), "Board diversity: Beginning to unpeel the onion", Corporate Governance: An International Review, Vol.23 No.2, pp.104-107. 
Javed, A.Y., and Iqbal, R. (2006), "Corporate governance and firm performance: Evidence from Karachi Stock Exchange”, The Pakistan Development Review, Vol.45 No.4, pp.947-964.

Javeed, A., Hassan, M., and Azeem, M. (2014), "Interrelationship among capital structure, corporate governance measures and firm value: panel study from Pakistan", Pakistan Journal of Commerce and Social Sciences, Vol. 8 No. 3, pp. 572-589.

Jensen, M.C., and Meckling, W.H. (1976), "Theory of the firm: Managerial behavior, agency costs and ownership structure", Journal of Financial Economics, Vol.3 No.4, pp.305-360.

Jong, A.d., DeJong, D.V., Mertens, G., and Wasley, C.E. (2005), "The role of self-regulation in corporate governance: evidence and implications from The Netherlands", Journal of Corporate Finance, Vol.11 No.3, pp.473-503.

Kumar, P., and Zattoni, A. (2016), "Corporate governance, board gender diversity and firm performance”. Corporate Governance: An International Review, Vol. 24 No 4, pp.388-389.

Kutum, I. (2015). "Board characteristics and firm performance: evidence from Palestine", European Journal of Accounting Auditing and Finance Research, Vol.3 No.3, pp.32-47.

Kwansa, F.A., Song, Y., Sharma, A. and Gong, Y. (2014), "Link between executive stock ownership and corporate financial performance", The Journal of Hospitality Financial Management, Vol. 22 No. 2, pp. 111-122.

Liu, Y., Miletkov, M., Wei, Z., and Yang, T. (2015), "Board independence and firm performance in China”. Journal of Corporate Finance, Vol 30, pp. 223-244.

Malik, M.S., and Zahoor, N. (2016), "Do Females in Top Management Affect Firm Performance? Evidence from Pakistan”, Pakistan Journal of Gender Studies, Vol. 12, pp.101112.

Marriage, M. (2017), "BlackRock, Vanguard and State Street bulk up governance staff", available at: https://www.ft.com/content/657b243c-e492-11e6-9645-c9357a75844a.

Mashayekhi, B., and Bazaz, M. S. (2008), "Corporate governance and firm performance in Iran”, Journal of Contemporary Accounting \& Economics, Vol. 4 No. 2, pp. 156-172.

Mathew, S., Ibrahim, S., and Archbold, S. (2016), "Boards attributes that increase firm risk evidence from the UK", Corporate Governance: The International Journal of Business in Society, Vol. 16 No. 2, pp.233-258.

Mura, R. (2007), "Firm performance: Do non-executive directors have minds of their own? Evidence from UK panel data”, Financial Management, Vol. 36 No. 3, pp.81-112.

Nguyen, H., and Faff, R. (2007), "Impact of board size and board diversity on firm value: Australian evidence”, Corporate Ownership and Control. Vol. 4 No. 2, pp.24-32 
Parrino, R., Sias, R.W., and Starks, L.T. (2003), "Voting with their feet: Institutional ownership changes around forced CEO turnover”, Journal of Financial Economics, Vol.68 No.1, pp.346.

Pearce, J.A., and Zahra, S.A. (1992), "Board composition from a strategic contingency perspective”, Journal of Management Studies, Vol.29 No.4, pp.411-438.

Salman, F., and Siddiqui, K. (2013), "Corporate Governance in Pakistan: from the Perspective of Pakistan Institute of Corporate Governance", The IUP Journal of Corporate Governance, Vol. 12 No. 4, pp. 17-21.

Securities Exchange Commission of Pakistan (SECP) (2002), "Code of Corporate Governance 2002", available at: www.secp.gov.pk/corporate-governance/listed-companies/.

Securities Exchange Commission of Pakistan (SECP) (2014), "Code of Corporate Governance 2012 Amended July 2014", available at: www.secp.gov.pk/corporate-governance/listedcompanies/.

Sheikh, N.A., Wang, Z., and Khan, S. (2013), "The impact of internal attributes of corporate governance on firm performance", International Journal of Commerce and Management, Vol. 23 No. 1, pp. 38-55.

Sundarasen, S.D.D., Je-Yen, T. and Rajangam, N. (2016), "Board composition and corporate social responsibility in an emerging market", Corporate Governance: The International Journal of Business in Society, Vol. 16 No. 1, pp.35-53.

Tariq, Y.B., and Abbas, Z. (2013), "Compliance and multidimensional firm performance: evaluating the efficacy of rule-based code of corporate governance", Economic Modelling, Vol. 35 , pp. 565-575.

Vafeas, N. (1999), "Board meeting frequency and firm performance", Journal of Financial Economics, Vol.53 No.1, pp.113-142.

Weir, C. (1997), "Corporate governance, performance and take-overs: An empirical analysis of UK Mergers", Applied Economics, Vol.29 No.11, pp.1465-1475.

Yasser, Q.R. (2011), "Corporate governance and firm performance: An analysis of family and non-family controlled firms", The Pakistan Development Review, Vol. 50 No.1, pp. 47-62.

Yekini, K., Adelopo, I., Androkopolous, P. and Yekini, S., (2015), "Impact of board independence on the quality of community disclosures in annual reports", Accounting Forum, Vol. 39 No.4, pp.249-267.

Yusr, M.M., Othman, A.R., and Mokhtar, S.S.M. (2012), "Assessing the mediating role of marketing capability in the relationship between TQM practices and innovation performance dynamic capabilities approach", International Journal of Business and Social Science, Vol. 3 No. 23, pp. 165-176. 


\section{Table 1}

A comparison of the CG code 2002 and the revised CG code 2012

\begin{tabular}{|c|c|c|}
\hline CG provisions & CG code 2002 & CG code 2012 \\
\hline Board Evaluation & Not specified & $\begin{array}{l}\text { Annual evaluation of the } \\
\text { performance of the Board } \\
\text { within two years of } \\
\text { implementation of CG code } \\
2012\end{array}$ \\
\hline Board Independence & $\begin{array}{l}\text { One independent director on the } \\
\text { board is recommended }\end{array}$ & $\begin{array}{l}\text { At least one independent } \\
\text { director on the board and } \\
\text { one-third of the board are } \\
\text { recommended to be } \\
\text { independent directors }\end{array}$ \\
\hline Executive Directors & $\begin{array}{c}\text { Maximum } 75 \% \text { of the directors } \\
\text { on the board are executive } \\
\text { directors }\end{array}$ & $\begin{array}{l}\text { Maximum 1/3rd of the } \\
\text { directors on the board are } \\
\text { executive directors }\end{array}$ \\
\hline Board Leadership & $\begin{array}{l}\text { The chairman should be non- } \\
\text { executive director }\end{array}$ & $\begin{array}{c}\text { The chairman and CEO } \\
\text { should not be the same } \\
\text { person }\end{array}$ \\
\hline Gender Diversity & Not specified & $\begin{array}{l}\text { Diversified board is } \\
\text { recommended }\end{array}$ \\
\hline Audit Committee & $\begin{array}{l}\text { The chairman should be non- } \\
\text { executive director }\end{array}$ & $\begin{array}{c}\text { Audit Committee should } \\
\text { comprise of non-executive } \\
\text { directors }\end{array}$ \\
\hline
\end{tabular}

The above table was derived from SECP (2002) and SECP (2014). 
Table 2

Sample and Industry

\begin{tabular}{lcc}
\hline Industry & No of firms & \% of sample \\
\hline Basic Material & 9 & 14 \\
Oil and Gas & 6 & 9 \\
Industrial & 15 & 24 \\
Consumer goods and services & 22 & 34 \\
Utilities & 7 & 11 \\
Other & 5 & 8 \\
\hline Final sample & 64 & 100 \\
\hline
\end{tabular}




\section{Table 3}

Variables Definition and Measurement

Dependent variables

ROA

ROE

Tobin's Q

MTB

Independent variables

BS

IND

DIV

$\mathrm{MO}$

IO

$\mathrm{BM}$

Control variables

LEV

AGE

SIZE

IND

YEAR
Profit before tax as percentage of total asset

Profit after tax as percentage of total equity

The book value of long-term debt and market value of the equity divided by the book value of the total asset

Market value of firm divided by book value of firm

Number of executive and non-executive directors.

Number of independent non-executive directors divided by the number of board members.

Number of female directors divided by the number of board members.

Ordinary shares held by directors as percentage of total ordinary shares.

Dummy variable for institutional shareholding where value is 1 if the institutional shareholding is greater than 5\%, 0 otherwise.

The number of board meetings.

Ratio of total debt to total assets

Years since firm was incorporated (Year of incorporation is included)

The natural $\log$ of sales

Dummy variables for each of the six industries: basic material;

Oil and Gas; Industrial; Consumer goods and services; Utilities;

Other.

Dummy variables for the years 2011, 2012 and 2013 


\section{Table 4}

Panel A: Descriptive statistics for full sample

\begin{tabular}{|c|c|c|c|c|}
\hline & \multicolumn{3}{|c|}{ Full Sample } & \multirow[b]{2}{*}{ SD } \\
\hline & MEAN & MIN & MAX & \\
\hline \multicolumn{5}{|c|}{ Performance Measures } \\
\hline ROA & 13.123 & -13.992 & 59.725 & 10.944 \\
\hline ROE & 19.331 & -35.442 & 97.494 & 17.091 \\
\hline Tobin's q & 1.844 & 0.281 & 12.972 & 1.821 \\
\hline MTB & 2.802 & 0.420 & 34.06 & 4.731 \\
\hline \multicolumn{5}{|c|}{ CG Mechanisms } \\
\hline $\mathrm{BS}$ & 8.559 & 6 & 15 & 1.812 \\
\hline IND & 0.232 & 0 & 0.929 & 0.163 \\
\hline DIV & 0.050 & 0 & 0.429 & 0.090 \\
\hline MO & 11.248 & 0 & 70.398 & 17.063 \\
\hline IO & 0.823 & 0 & 1 & 0.383 \\
\hline $\mathrm{BM}$ & 5.216 & 3 & 13 & 1.373 \\
\hline \multicolumn{5}{|c|}{ Control Variables } \\
\hline LEV & 0.478 & 0.006 & 0.888 & 0.214 \\
\hline AGE & 38.031 & 3 & 154 & 24.515 \\
\hline SIZE & 9.581 & 0 & 12.432 & 2.228 \\
\hline
\end{tabular}

Variables are described as follows: return on assets (ROA), return on equity (ROE), Tobin's $\mathrm{Q}(\mathrm{Q})$, Market to Book (MTB), board size (BS), the proportion of independent non-executive directors (IND), board gender diversity (DIV), managerial ownership (MO), institutional ownership (IO), board meeting (BM), leverage (LEV), firm age (AGE) and firm size (SIZE). 


\section{Table 4}

Panel B: Descriptive statistics for performance measures before and after 2012

\begin{tabular}{lccccccccc}
\hline & \multicolumn{4}{c}{ Pre-2012 } & \multicolumn{4}{c}{ Post-2012 } & \multicolumn{2}{c}{ Change (\%) } \\
& MEAN & MIN & MAX & SD & MEAN & MIN & MAX & SD & MEAN \\
\hline Performance Measures & & & & & & & & & \\
ROA & 11.924 & -7.379 & 59.725 & 11.722 & 14.272 & -13.992 & 43.372 & 10.055 & 19.69 \\
ROE & 17.586 & -35.442 & 97.494 & 18.982 & 21.003 & -18.102 & 80.054 & 14.943 & 19.43 \\
Tobin's q & 1.386 & 0.281 & 5.42 & 1.007 & 2.263 & 0.321 & 12.972 & 2.255 & 63.28 \\
MTB & 1.842 & 0.420 & 21.390 & 2.861 & 3.748 & 0.400 & 34.060 & 5.882 & 103.47 \\
\hline
\end{tabular}

Panel C: Descriptive statistics for corporate governance mechanisms before and after 2012

\begin{tabular}{lcccccccccc}
\hline & \multicolumn{3}{c}{ Pre-2012 } & & & Post-2012 & $\begin{array}{c}\text { Change } \\
(\%)\end{array}$ \\
\hline & MEAN & MIN & MAX & SD & MEAN & MIN & MAX & SD & MEAN \\
CG Mechanisms & & & & & & & & & \\
BS & 8.560 & 7 & 15 & 1.802 & 8.558 & 6 & 15 & 1.8278 & 0 \\
IND & 0.267 & 0 & 0.929 & 0.195 & 0.208 & 0 & 0.857 & 0.135 & -22.10 \\
DIV & 0.044 & 0 & 0.375 & 0.085 & 0.054 & 0 & 0.429 & 0.093 & 22.72 \\
MO & 11.473 & 0 & 70.398 & 17.745 & 11.036 & 0 & 67.484 & 16.475 & -3.80 \\
IO & 0.792 & 0 & 1 & 0.408 & 0.846 & 0 & 1 & 0.361 & 6.81 \\
BM & 5.292 & 4 & 13 & 1.412 & 5.142 & 3 & 11 & 1.335 & -2.83 \\
\hline
\end{tabular}




\section{Table 5}

Pearson Correlation Matrix

\begin{tabular}{|c|c|c|c|c|c|c|c|c|c|c|c|c|c|}
\hline & ROA & ROE & Q & MTB & BS & IND & DIV & $\mathrm{MO}$ & $\mathrm{IO}$ & $\mathrm{BM}$ & LEV & AGE & SIZE \\
\hline ROA & 1 & & & & & & & & & & & & \\
\hline ROE & $.809 * *$ & 1 & & & & & & & & & & & \\
\hline Q & $.476^{* *}$ & $.463 * *$ & 1 & & & & & & & & & & \\
\hline МТВ & $.323 * *$ & $.477 * *$ & $.880 * *$ & 1 & & & & & & & & & \\
\hline BS & -0.021 & 0.1 & 0.033 & 0.026 & 1 & & & & & & & & \\
\hline IND & -0.125 & -0.111 & -0.127 & -0.102 & 0.108 & 1 & & & & & & & \\
\hline DIV & $.292 * *$ & $.333 * *$ & 0.048 & 0.032 & $.213 * *$ & 0.041 & 1 & & & & & & \\
\hline MO & 0.046 & 0.071 & -0.055 & -0.069 & $-.205^{* *}$ & 0.041 & -0.028 & 1 & & & & & \\
\hline IO & $-.196 * *$ & $-.278 * *$ & $-.536 * *$ & $-.524 * *$ & -0.01 & 0.115 & 0.055 & -0.071 & 1 & & & & \\
\hline $\mathrm{BM}$ & -0.125 & -0.027 & -0.103 & -0.115 & $.226 * *$ & $.203^{* *} *$ & 0.067 & 0.125 & 0.112 & 1 & & & \\
\hline LEV & $-.166^{*}$ & -0.097 & -0.06 & 0.045 & 0.087 & 0.009 & -0.007 & 0 & 0.017 & 0.039 & 1 & & \\
\hline AGE & 0.102 & -0.089 & $.169 *$ & 0.082 & -0.014 & 0.145 & -0.031 & 0.001 & $-.174 *$ & $-.148 *$ & -0.068 & 1 & \\
\hline SIZE & $.130 *$ & $.223 * *$ & 0.039 & 0.084 & -0.114 & -0.111 & 0.069 & -0.084 & -0.113 & $-.251 * *$ & $-.258 * *$ & -0.082 & 1 \\
\hline
\end{tabular}

***,** and * represent significant at $0.01,0.05$ and 0.10 respectively. Variables are described as follows: return on assets (ROA), return on equity (ROE),

Tobin's Q (Q), Market to Book (MTB), board size (BS), the proportion of independent non-executive directors (IND), board gender diversity (DIV),

managerial ownership (MO), institutional ownership (IO), board meeting (BM), leverage (LEV), firm age (AGE) and firm size (SIZE). 
Table 6

VIF

\begin{tabular}{lcc} 
Variable & Tolerance & VIF \\
\hline BS & 0.589 & 1.698 \\
IND & 0.561 & 1.783 \\
DIV & 0.646 & 1.548 \\
MO & 0.647 & 1.545 \\
IO & 0.568 & 1.761 \\
BM & 0.736 & 1.358 \\
LEV & 0.535 & 1.870 \\
AGE & 0.548 & 1.824 \\
SIZE & 0.535 & 1.868 \\
\hline
\end{tabular}

Variables are described as follows: board size (BS), the proportion of independent nonexecutive directors (IND), board gender diversity (DIV), managerial ownership (MO), institutional ownership (IO), board meeting (BM), leverage (LEV), firm age (AGE) and firm size (SIZE). 


\section{Table 7}

The impact of corporate governance mechanisms on firm performance using Fixed-Effects Models

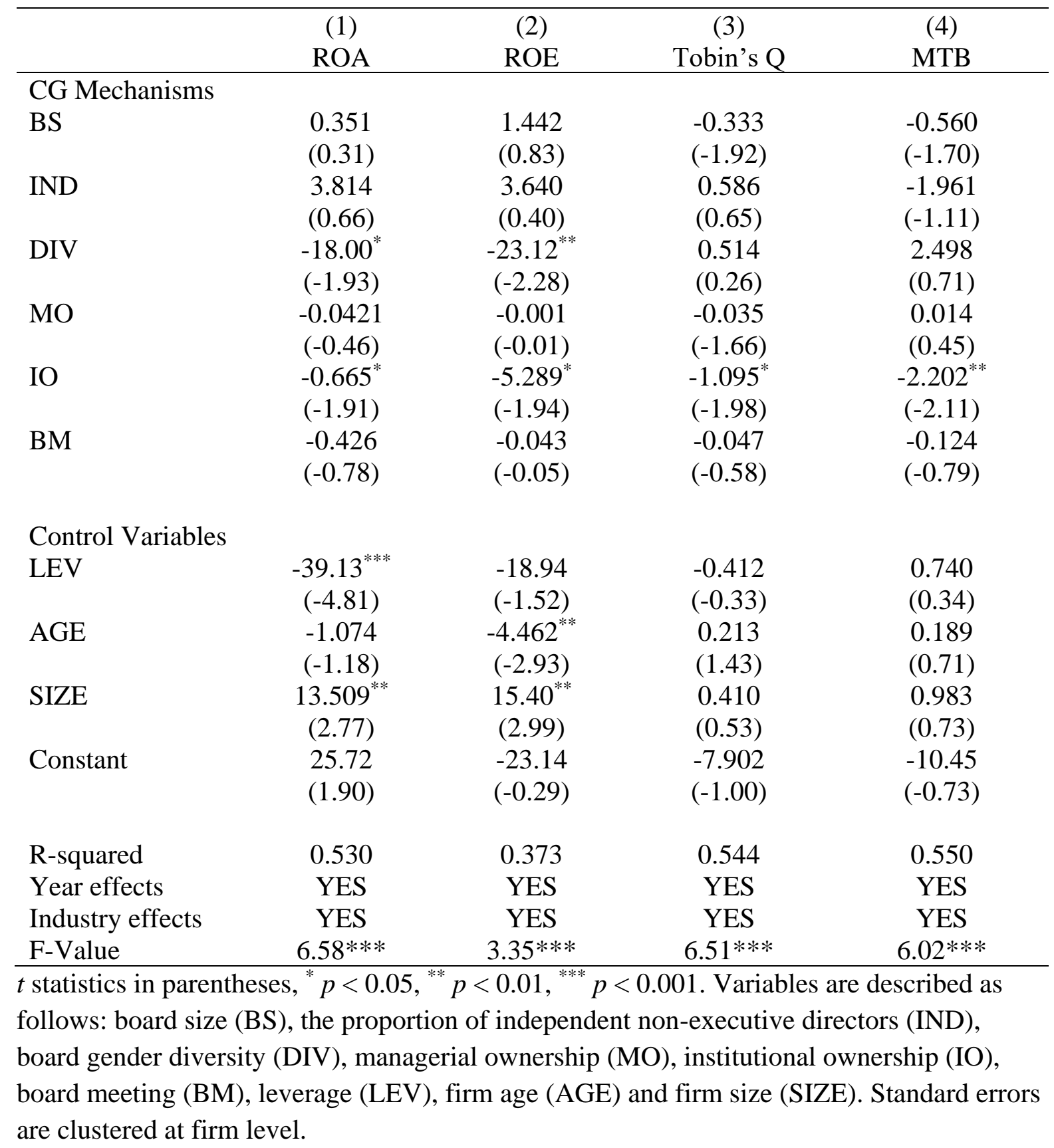




\section{Table 8}

The impact of corporate governance mechanisms on firm performance using Two-Stage Least Squares (2SLS)

\begin{tabular}{lcccc}
\hline & $(1)$ & $(2)$ & $(3)$ & $(4)$ \\
VARIABLES & ROA & ROE & Tobin's Q & MTB \\
\hline CG Mechanisms & & & & \\
BS & 1.204 & 1.454 & -0.003 & -0.878 \\
& $(0.559)$ & $(0.392)$ & $(-0.031)$ & $(-1.516)$ \\
IND & 27.67 & 6.911 & $6.224 * *$ & 0.130 \\
& $(1.081)$ & $(0.191)$ & $(2.009)$ & $(0.010)$ \\
DIV & 7.735 & -13.62 & -3.780 & $-39.54 *$ \\
& $(0.243)$ & $(-0.310)$ & $(-0.752)$ & $(-1.856)$ \\
MO & $0.410 *$ & 0.554 & 0.023 & 0.065 \\
& $(1.662)$ & $(1.500)$ & $(1.345)$ & $(0.529)$ \\
IO & $-13.67 * * *$ & $-23.13 * * *$ & $-6.429 * * *$ & $-15.90 * * *$ \\
& $(-2.749)$ & $(-3.468)$ & $(-6.776)$ & $(-3.609)$ \\
BM & -4.923 & -1.563 & 0.356 & 5.036 \\
& $(-1.226)$ & $(-0.286)$ & $(0.456)$ & $(1.521)$ \\
Control Variables & & & & \\
LEV & 1.115 & $39.35 * * *$ & 1.112 & 9.673 \\
& $(0.113)$ & $(2.884)$ & $(1.026)$ & $(1.479)$ \\
AGE & 0.126 & 0.212 & -0.009 & 0.003 \\
SIZE & $(0.968)$ & $(1.138)$ & $(-0.750)$ & $(0.044)$ \\
& -0.743 & 0.439 & -0.007 & 1.348 \\
Constant & $(-0.367)$ & $(0.137)$ & $(-0.035)$ & $(1.228)$ \\
& 41.67 & 8.865 & 4.866 & -22.12 \\
R-squared & $(0.984)$ & $(0.130)$ & $(0.848)$ & $(-1.119)$ \\
Year effects & & & & \\
Industry effects & 0.179 & 0.387 & 0.704 & 0.475 \\
F-Value & YES & YES & YES & YES \\
\hline & YES & YES & YES & YES \\
& $9.77 * * *$ & $14.14 * * *$ & $8.42^{* * * *}$ & $5.06 * * *$ \\
\hline
\end{tabular}

$t$ statistics in parentheses, ${ }^{*} p<0.05,{ }^{* *} p<0.01,{ }^{* * * *} p<0.001$. Variables are described as follows: board size (BS), the proportion of independent non-executive directors (IND), board gender diversity (DIV), managerial ownership (MO), institutional ownership (IO), board meeting (BM), leverage (LEV), firm age (AGE) and firm size (SIZE). Standard errors are clustered at firm level. 
Table 9

The impact of corporate governance mechanisms on firm performance Pre-2012 period

\begin{tabular}{|c|c|c|c|c|}
\hline & $\begin{array}{c}(1) \\
\text { ROA }\end{array}$ & $\begin{array}{c}(2) \\
\text { ROE }\end{array}$ & $\begin{array}{c}\text { (3) } \\
\text { Tobin's Q }\end{array}$ & $\begin{array}{c}(4) \\
\text { MTB }\end{array}$ \\
\hline \multirow[t]{2}{*}{ BS } & 0.039 & 0.040 & 0.038 & 0.226 \\
\hline & $(0.04)$ & $(0.03)$ & $(0.28)$ & $(0.84)$ \\
\hline \multirow[t]{2}{*}{ IND } & 6.011 & 5.731 & 1.950 & 3.994 \\
\hline & $(0.40)$ & $(0.28)$ & (1.09) & (1.18) \\
\hline \multirow{2}{*}{ DIV } & 17.68 & 21.67 & -0.146 & 0.038 \\
\hline & $(0.92)$ & $(0.83)$ & $(-0.06)$ & $(0.01)$ \\
\hline \multirow[t]{2}{*}{$\mathrm{MO}$} & 0.155 & 0.153 & 0.009 & 0.019 \\
\hline & (1.18) & $(0.85)$ & $(0.58)$ & $(0.66)$ \\
\hline \multirow[t]{2}{*}{ IO } & $-9.103^{* *}$ & $-11.58^{* * *}$ & $-2.243^{* * * *}$ & $-4.119^{* * * *}$ \\
\hline & $(-1.98)$ & $(-1.96)$ & $(-4.09)$ & $(-3.97)$ \\
\hline \multirow[t]{2}{*}{$\mathrm{BM}$} & -0.621 & -0.084 & 0.126 & -0.123 \\
\hline & $(-0.44)$ & $(-0.04)$ & $(0.74)$ & $(-0.38)$ \\
\hline \multirow[t]{2}{*}{ LEV } & -16.12 & 13.87 & -0.547 & 1.428 \\
\hline & $(-1.71)$ & (1.08) & $(-0.48)$ & $(0.66)$ \\
\hline \multirow[t]{2}{*}{ AGE } & 0.063 & 0.004 & -0.006 & -0.013 \\
\hline & $(0.67)$ & $(0.04)$ & $(-0.60)$ & $(-0.56)$ \\
\hline \multirow[t]{2}{*}{ SIZE } & 1.182 & 0.511 & -0.0189 & -0.219 \\
\hline & $(1.26)$ & $(0.40)$ & $(-0.17)$ & $(-1.05)$ \\
\hline \multirow[t]{2}{*}{ Constant } & 21.40 & 21.43 & $5.667^{* * *}$ & $9.968^{* *}$ \\
\hline & (1.38) & (1.02) & $(3.06)$ & $(2.71)$ \\
\hline R-squared & 0.312 & 0.220 & 0.368 & 0.380 \\
\hline Year effects & YES & YES & YES & YES \\
\hline Industry effects & YES & YES & YES & YES \\
\hline F-Value & $3.18^{* * *}$ & $2.73 * *$ & $3.06 * * *$ & $3.04 * * *$ \\
\hline
\end{tabular}




\section{Table 10}

The impact of corporate governance mechanisms on firm performance Post-2012 period

\begin{tabular}{|c|c|c|c|c|}
\hline & $\begin{array}{c}(1) \\
\text { ROA }\end{array}$ & $\begin{array}{c}(2) \\
\text { ROE }\end{array}$ & $\begin{array}{c}(3) \\
\text { Tobin's Q }\end{array}$ & $\begin{array}{c}(4) \\
\text { MTB }\end{array}$ \\
\hline \multirow[t]{2}{*}{$\mathrm{BS}$} & -0.092 & -0.296 & -0.110 & -0.260 \\
\hline & $(-0.12)$ & $(-0.25)$ & $(-0.87)$ & $(-0.70)$ \\
\hline \multirow[t]{2}{*}{ IND } & 20.84 & 28.00 & $5.416^{* *}$ & $13.02^{*}$ \\
\hline & (1.80) & (1.59) & $(2.92)$ & $(2.44)$ \\
\hline \multirow[t]{2}{*}{ DIV } & 2.569 & 2.276 & -1.786 & -6.531 \\
\hline & $(0.18)$ & $(0.11)$ & $(-0.75)$ & $(-0.88)$ \\
\hline \multirow[t]{2}{*}{ MO } & $0.304^{* *}$ & 0.282 & 0.001 & -0.02 \\
\hline & $(2.90)$ & (1.77) & $(0.08)$ & $(-0.48)$ \\
\hline \multirow[t]{2}{*}{$\mathrm{IO}$} & $-16.00^{* * *}$ & $-22.30^{* * *}$ & $-5.569^{* * *}$ & $-14.30^{* * * *}$ \\
\hline & $(-3.78)$ & $(-3.47)$ & $(-8.27)$ & $(-7.35)$ \\
\hline \multirow[t]{2}{*}{$\mathrm{BM}$} & 0.0820 & 0.477 & 0.119 & 0.111 \\
\hline & $(0.08)$ & $(0.31)$ & $(0.72)$ & $(0.22)$ \\
\hline \multirow[t]{2}{*}{ LEV } & -3.195 & $36.16^{* *}$ & 1.245 & $12.62^{* *}$ \\
\hline & $(-0.43)$ & (3.18) & (1.04) & $(3.45)$ \\
\hline \multirow[t]{2}{*}{ AGE } & 0.039 & 0.040 & -0.006 & 0.001 \\
\hline & $(0.53)$ & $(0.36)$ & $(-0.56)$ & $(0.00)$ \\
\hline \multirow[t]{2}{*}{ SIZE } & 0.936 & 0.583 & -0.052 & -0.463 \\
\hline & (1.44) & $(0.59)$ & $(-0.51)$ & $(-1.51)$ \\
\hline \multirow[t]{2}{*}{ Constant } & 21.99 & 15.75 & $8.844^{* * * *}$ & $18.23^{* * *}$ \\
\hline & (1.98) & $(0.93)$ & $(5.01)$ & $(3.50)$ \\
\hline R-squared & 0.349 & 0.379 & 0.690 & 0.677 \\
\hline Year effects & YES & YES & YES & YES \\
\hline Industry effects & YES & YES & YES & YES \\
\hline F-Value & $2.37 * *$ & $2.69 * *$ & $9.35 * * *$ & $8.39 * * *$ \\
\hline $\begin{array}{l}t \text { statistics in pare } \\
\text { follows: board si } \\
\text { board gender div } \\
\text { board meeting (B }\end{array}$ & $\begin{array}{l}{ }^{*} p<0 \\
\text { the pro } \\
\text { IV), me } \\
\text { erage (L }\end{array}$ & $\begin{array}{l}0.01,{ }^{* * *} \\
\text { indepenc } \\
\text { ownershil } \\
\text { age (AG }\end{array}$ & $\begin{array}{l}\text { 01. Variable } \\
\text { l-executive } \\
\text { institution } \\
\text { firm size ( } S\end{array}$ & $\begin{array}{l}\text { scribed as } \\
\text { s (IND), } \\
\text { ship (IO), }\end{array}$ \\
\hline
\end{tabular}


Appendix 1

\begin{tabular}{llll}
\hline & F-test & Lagrange Multiplier (LM) test & Hausman test \\
ROA & $15.85 * * *$ & $63.05^{* * *}$ & $39.27 * * *$ \\
ROE & $10.74 * * *$ & $66.92^{* * *}$ & $18.93^{*}$ \\
Tobin's q & $3.03^{* * *}$ & $2.78^{* *}$ & $38.82^{* * *}$ \\
MTB & $2.82^{* * *}$ & $3.64 * *$ & $22.30^{* *}$ \\
\hline${ }^{*} p<0.1,{ }^{* *} p<0.05,{ }^{* * *} p<0.01$. &
\end{tabular}

